\title{
Post-harvest quality of bananas Prata-anã and Nanica after application of exogenous ethylene in maturation
}

\author{
Regina Célia Gomes Garcia Nobre², Eliseu Marlônio Pereira de Lucena², Josivanda Palmeira Gomes ${ }^{3}$, \\ Dyalla Ribeiro de Araújo ${ }^{4}$, Dannaya Julliethy Gomes Quirino ${ }^{5}$
}

\begin{abstract}
The objective of this study was to evaluate the post-harvest quality of bananas (Musa $x$ paradisiaca L.) Prata-anã and Nanica after application of exogenous ethylene $\left(\mathrm{C}_{2} \mathrm{H}_{4}\right)$ during maturation. Bananas of Prata-anã cultivar were harvested 18 weeks after the anthesis (WAA) and those of Nanica cultivar with 13 WAA. After harvest, the fruits were submitted to $0,1,2,3$, 4 and 5 applications of $15 \mathrm{~mL}$ of ethyl-5/m $\mathrm{m}^{3}$ in refrigeration chambers at $15^{\circ} \mathrm{C}$ and later stored at room temperature $\left(24\right.$ to $\left.28^{\circ} \mathrm{C}\right)$ and refrigerated at $15^{\circ} \mathrm{C}$ for 10 days. Peel color, fresh weight loss, firmness, total soluble solids, total bark chlorophyll, total bark and pulp carotenoids were evaluated at $0,3,4,7$ and 10 days after harvest (DAH). The Assistat program was used in statistical analysis. Among the storage conditions, fruits kept under refrigeration had a longer shelf life. The Prata-anã cultivar was superior to Nanica, presenting maturation indexes ideal for transport and commercialization, evaluated for the interactions of storage temperature, ethylene $\left(\mathrm{C}_{2} \mathrm{H}_{4}\right)$ applications and storage time. It was concluded that the banana Prata-anã requires 3 and Nanica 4 applications of ethyl, for the harvest with 18 and 13 weeks, respectively, in order to promote a fast and uniform maturation.
\end{abstract}

Index terms: Musa x paradisiaca, post-harvest physiology, storage.

\section{Qualidade pós-colheita de bananas Prata-anã e Nanica após aplicação de etileno exógeno na maturação}

Corresponding author: reginacggn@yahoo.com.br

Received: November 17, 2017. Accepted: April 02, 2018.

Copyright: All the contents of this journal, except where otherwise noted, is licensed under a Creative Commons Attribution License.

\section{(cc) $\mathrm{EY}$}

Resumo - Objetivou-se com o presente trabalho avaliar a qualidade pós-colheita de bananas (Musa $x$ paradisiaca L.) Prata-Anã e Nanica após aplicação de etileno $\left(\mathrm{C}_{2} \mathrm{H}_{4}\right)$ exógeno na maturação. As bananas da cultivar Prata-Anã foram colhidas com 18 semanas após a antese (SAA), e as da cultivar Nanica,com 13 SAA. Após a colheita, os frutos foram submetidos a $0 ; 1 ; 2 ; 3 ; 4$ e 5 aplicações de $15 \mathrm{~mL}$ de etil $/ \mathrm{m}^{3}$, em câmaras de refrigeração a $15^{\circ} \mathrm{C}$ e posteriormente armazenados em temperatura ambiente $\left(24\right.$ a $\left.28^{\circ} \mathrm{C}\right)$ e refrigerados a $15^{\circ} \mathrm{C}$, durante 10 dias. Avaliaram-se coloração da casca, perda de massa fresca, firmeza, sólidos solúveis totais, clorofila total da casca, carotenoides totais da casca e da polpa, aos $0 ; 3 ; 4 ; 7$ e 10 dias após a colheita (DAC). Utilizou-se o programa Assistat nas análises estatísticas. Dentre as condições de armazenamento, os frutos mantidos sob refrigeração tiveram maior vida útil. A cultivar Prata-Anã foi superior à Nanica, apresentando índices de maturação ideais para o transporte e a comercialização precocemente, avaliados quanto às interações de temperatura de armazenamento, aplicações de etileno $\left(\mathrm{C}_{2} \mathrm{H}_{4}\right)$ e tempo de armazenamento. Conclui-se que a banana Prata-Anã necessita de 3 e a Nanica de 4 aplicações de etil, para a colheita com 18 e 13 semanas, respectivamente, a fim de promover uma rápida e uniforme maturação.

Termos para indexação: Musa x paradisiaca, fisiologia pós-colheita, armazenamento.

\footnotetext{
${ }^{1} \mathrm{PhD}$ in Agricultural Engineering, Professor of the Technical Vocational Center, CVTEC Crato Campus, Crato-CE, Brazil. E-mail: reginacggn@ yahoo.com.br

${ }^{2} \mathrm{PhD}$ in Agronomy, Associate Professor of the Biological Sciences Course, CCS/UECE, Fortaleza-CE, Brazil. E-mail: eliseu.lucena@uece.br ${ }^{3} \mathrm{PhD}$ in Food Engineering, Full Professor of the Department of Agricultural Engineering, CTRN/UFCG, Campina Grande-PB, Brazil. E-mail: josivanda@gmail.com

${ }^{4} \mathrm{PhD}$ in Agricultural Engineering, Professor of the Federal Institute of Ceara, IFCE Crato Campus, Crato-CE, Brazil. E-mail: dyalla@ifce.edu.br ${ }^{5}$ Food Technologist, Centec Technology Colleges, FATEC Cariri, Juazeiro do Norte-CE, Brazil. E-mail: dannaya_gomes@yahoo.com
} 


\section{Introduction}

The world banana production in 2014 reached 114.13 million tons, moving around US $\$ 40.45$ billion (FAO, 2014). In Brazil it is the most consumed fruit in natura, with production of 7.27 million tons in a planted area of 491,435 ha (IBGE, 2015).

About $85 \%$ of world banana production is consumed in producing countries, while the remaining $15 \%$ is exported to developed countries, almost exclusively from the AAA genotype (Cavendish subgroup), which includes the cultivars Nanica, Nanicão and Grande Naine. From the not exported bananas, $25 \%$ are predominantly of the Cavendish subgroup and the other $75 \%$ consist of a wide range of various cultivars, which are highly locally valued. These local cultivars are under as much threat as the Cavendish subgroup, that receives little international publicity (DALE et al., 2017).

The production and consumption of bananas in Brazil show very peculiar characteristics in the preference of Brazilians, since in most Brazilian regions, prevail the cultivars of the AAB genotype group (Prata subgroup), such as, Prata, Prata-comum, Prata-anã and Pacovan, which represent about $80 \%$ of the commercialized banana (MAIA et al., 2015). Almost all the "Prata-anã" bananas produced in Brazil are sold in the domestic market. However, with the saturation of the market in certain periods of the year, the price reduction occurs (SANTOS et al., 2017).

The banana production in the State of Ceará is feasible with regards to the ideal climatic conditions for crops, although rainfall is very low, which may make it difficult to establish fruit production if irrigation equipment is not used, being of great importance for satisfactory harvests (MORENO et al., 2016).

The municipal district of Missão Velha, located in the south of the state more precisely in the Cariri region, is the eighth Brazilian municipality in banana production in the country, according to the IBGE (2016) survey for municipal agricultural production of permanent crops in 2015. According to this survey, 89.7 thousand tons of bananas were produced, with 2.8 thousand hectares of harvested area and the participation of $1.3 \%$ of the total national production. In relation to the previous year, 2014, the production in the city had the highest growth among the 20 leading municipalities in the production of the product, with advance of $607.6 \%$.

The characterization of the banana fruits allows to identify relative differences of each cultivar, making possible to obtain information that can guide the harvest, the internal and external transport and the packages, based on the susceptibility to mechanical damages, ease of falling out, fruit size, color, form of presentation and flavor, directed according to the requirements of the market (CASTRICINI et al., 2015).
Physical, chemical and physicochemical transformations are the main causes of quality loss during storage. Thus, the storage carried out in a suitable way becomes of great value so that such transformations do not harm the commercialization, as well as the use of post-harvest technology that allows to preserve the quality of the fruits (PEREIRA et al., 2015).

Through the acclimatization, banana ripening takes place under controlled temperature and relative humidity conditions; this strategy, coupled with the use of ethylene gas $\left(\mathrm{C}_{2} \mathrm{H}_{4}\right)$, which is the phytohormone responsible for ripening, it is frequently used by banana growers. The exogenous ethylene $\left(\mathrm{C}_{2} \mathrm{H}_{4}\right)$, known as ethyl-5, that is a mixture of $5 \%$ ethylene $\left(\mathrm{C}_{2} \mathrm{H}_{4}\right)$ and $95 \%$ nitrogen, is applied inside a refrigerated chamber and promotes acceleration of the banana respiratory rate causing rapid maturation. It is worth noting that the recommended dose is directly related to the size of the chamber, the volume of the stored bananas and the risk of simultaneous hatching of the banana maturation according to the cultivar (PAULO, 2010).

The objective of this study was to evaluate the post-harvest quality of bananas (Musa x paradisiaca L.) Prata-anã and Nanica after application of exogenous ethylene $\left(\mathrm{C}_{2} \mathrm{H}_{4}\right)$ in maturation.

\section{Material and methods}

This study was carried out in the banana plantation at Fazenda Sítio Barreiras, located in the municipality of Missão Velha, located in the southern region of the State of Ceará, latitude $07^{\circ} 14^{\prime} 59^{\prime \prime} \mathrm{S}$ and longitude $39^{\circ} 08^{\prime} 35^{\prime \prime}$ $\mathrm{W}$, altitude of $360 \mathrm{~m}$. The region has tropical warm mild semiarid and tropical warm semi-arid climate, with rainfall from January to April and annual precipitation of 987.3 $\mathrm{mm}$.

The bananas (Musa x paradisiaca L.) of the Prataanã cultivar were harvested 18 weeks after the anthesis (WAA) and the Nanica cultivar with 13 WAA.

After harvesting, the fruits were manually selected in order to eliminate those that presented physical damages or rot appearance, giving relevance to the best-looking bananas; then we realized the sanitization by washing the bananas in current drinking water with aluminum sulfate at $28^{\circ} \mathrm{C}$, to eliminate dirt from the harvest. The banana bouquets for the two cultivars, Prata-anã and Nanica, were packed in polyethylene boxes and stored under refrigeration at $15 \pm 1{ }^{\circ} \mathrm{C}$ and $85-95 \%$ relative humidity until the pulp temperature reached $15^{\circ} \mathrm{C}$. Finally, 1, 2, 3,4 and 5 applications of $15 \mathrm{~mL}$ of ethyl $/ \mathrm{m}^{3}$ in both cultivars of the bananas studied were performed, as well as maintenance of the control treatment for both cultivars, that is, without application of ethylene $-\mathrm{C}_{2} \mathrm{H}_{4}$ (Table 1). The interval between one and another ethylene application 
$\left(\mathrm{C}_{2} \mathrm{H}_{4}\right)$ was 12 hours, with exhaustion of carbon dioxide every 12 hours for 30 minutes.

After the treatments, the bananas were transported in a refrigerated trunk truck to the Chemistry laboratory of the Technical Vocational Center - CVTEC, Crato, CE, belonging to the Center for Technological Teaching CENTEC, where the bananas plots from each cultivar were distributed for storage at room temperature (24 to $\left.28^{\circ} \mathrm{C}\right)$ and refrigerated storage $\left(15^{\circ} \mathrm{C} \pm 1^{\circ} \mathrm{C}\right)$, identifying the treatments and replicates (4 replicates, consisting of 4 bananas each) in polystyrene trays.

The samples stored at room temperature and refrigerated were analyzed at $0,3,4,7$ and 10 days after harvest (DAH) for physical, physical-chemical and chemical characteristics.

The color of the banana peel at the different maturation stages was determined on the basis of the Von Loesecke maturity scale (PBMH \& PIF, 2006): 1 - Totally green; 2 - Green with yellow traces; 3 - Greener than yellow; 4 - More yellow than green; 5 - Yellow with green tip; 6 - Yellow; 7 - Yellow with brown areas (Figure 1). The results were attributed through the average grade of the repetitions, with individual examination of each banana.

The mass loss was determined by weighing the fruits individually at each storage time interval using a balance of $0.1 \mathrm{~g}$ precision. All weightings were expressed in grams and the weight loss was determined as a percentage by considering the difference between the initial mass of the fruit and that obtained at each storage time interval.
The banana firmness was determined as described by Chitarra and Chitarra (2005), in which the measurement was performed transversely in the median region of the banana pulp with penetrometer (Instrutherm PTR - 100), whose tip measures $8 \mathrm{~mm}$. The values found in pound strength (Lbf) were multiplied by 4.4482 , to express the value in Newton $(\mathrm{N})$.

The total soluble solids content was determined using an Abbe analog refractometer with a 0 to $32^{\circ}$ Brix scale and temperature correction according to IAL (2008) analytical standards.

The chlorophyll and total carotenoids were determined by the method of Lichtenthaler (1987). Chlorophyll content was estimated from the reading of absorbance at 646.8 and $663.2 \mathrm{~nm}$, while the carotenoid content was $646.8,663.2$ and $470 \mathrm{~nm}$. The results for both analyzes were expressed in $\mathrm{mg} / 100 \mathrm{~g}$. Chlorophyll and total carotenoids of the bark were determined, as well as total carotenoids of the pulp.

The experimental design was a completely randomized design, and the treatments were arranged in factorial scheme 2 (Prata-anã and Nanica) x 2 (ambient and refrigerated) $\times 6(0,1,2,3,4$ and 5 ethylene applications $\left.-\mathrm{C}_{2} \mathrm{H}_{4}\right) \times 5(0,3,4,7$ and $10 \mathrm{DAH})$ and four replicates consisting of four fruits each. The results were submitted to analysis of variance observing the significance by the F test and when significant, the Tukey test was carried out at the $5 \%$ probability level, using the Assistat 7.7 statistic program (SILVA; AZEVEDO, 2016).

Table 1. Treatments of ethyl with two banana cultivars.

\begin{tabular}{cccc}
\hline \multicolumn{3}{c}{ Treatments } \\
\hline Prata-anã (PA) & \multicolumn{2}{c}{ Nanica (NA) } \\
\hline $\begin{array}{c}\text { Environment } \\
\left(\mathbf{2 4} \text { to } \mathbf{2 8}^{\circ} \mathbf{C}\right)\end{array}$ & $\begin{array}{c}\text { Refrigerated } \\
\left(\mathbf{1 5} \pm \mathbf{1}^{\circ} \mathbf{C}\right)\end{array}$ & $\begin{array}{c}\text { Environment } \\
\left(\mathbf{2 4} \text { to } \mathbf{2 8}^{\circ} \mathbf{C}\right)\end{array}$ & $\begin{array}{c}\text { Refrigerated } \\
\left(\mathbf{1 5} \pm \mathbf{1}^{\circ} \mathbf{C}\right)\end{array}$ \\
\hline Control & Control & Control & Control \\
1 Ethyl application & 1 Ethyl application & 1 Ethyl application & 1 Ethyl application \\
2 Ethyl applications & 2 Ethyl applications & 2 Ethyl applications & 2 Ethyl applications \\
3 Ethyl applications & 3 Ethyl applications & 3 Ethyl applications & 3 Ethyl applications \\
4 Ethyl applications & 4 Ethyl applications & 4 Ethyl applications & 4 Ethyl applications \\
5 Ethyl applications & 5 Ethyl applications & 5 Ethyl applications & 5 Ethyl applications \\
\hline
\end{tabular}

\section{Results and discussion}

The values for fruit peel coloration of Prata-anã and Nanica bananas when stored under ambient conditions were higher than those stored under refrigeration, and the color of Prata-anã cultivar was higher than the Nanica one, regardless of the storage condition (Figure 2A). This behavior was expected because the bananas under ambient conditions ( 24 to $28^{\circ} \mathrm{C}$ ) have the fastest metabolism because the temperature is higher than the refrigerated storage $\left(15^{\circ} \mathrm{C} \pm 1^{\circ} \mathrm{C}\right)$ and the Prata-anã cultivar was superior because it was harvested later (18 weeks after anthesis - WAA) than Nanica (13 WAA). The above results are corroborated by Paulo (2010), when studying the effect of ethylene $-\mathrm{C}_{2} \mathrm{H}_{4}(12.5,25,50$, and $100 \mathrm{~mL})$ and temperatures in the acclimatization $\left(13,17\right.$ and $\left.21^{\circ} \mathrm{C}\right)$ of the Prata-anã and Grande Naine cultivars (Cavendish subgroup), because for both cultivars the degreening was higher at $21^{\circ} \mathrm{C}$ and lower at $13^{\circ} \mathrm{C}$, as well as, the degreening of the Prata-anã cultivar was higher than the Grande Naine 
cultivar, independent of the storage condition.

Figure 2B shows increases in the color of the peel as the number of ethylene $\left(\mathrm{C}_{2} \mathrm{H}_{4}\right)$ applications for both cultivars has increased, except in the fourth and fifth applications, which did not differ among them, therefore, it is suggested the use of only four applications, so this reduces the production cost. Comparing the two cultivars, Prata-anã showed superior coloring value in all applications. Thus, these results are supported by research by Aquino et al. (2017) that when studying the physical and chemical characteristics of the fruits of the Prata-anã and Nanica cultivars in the pre-climacteric phase and after maturation, reported that the fruits of both cultivars presented in the stage of maturation 1 totally green peels and with the advancement of maturation the Prata-anã showed a strong yellow color, while the Nanica turned greenish-yellow, proving that Prata-anã had the fastest ripening process.

The coloring of the peel was increasing during the storage time for the Prata-anã and Nanica cultivars (Figure 2C), being the Prata-anã cultivar superior at all times reaching the yellow color (stage 6, ripe fruit) at 7 days after harvest (DAH), while the Nanica cultivar did not reach this color at the end of storage (stage 5, mature fruit at $10 \mathrm{DAH})$. These results for Prata-anã are similar to those of Sarmento et al. (2015), when studying the Prata-catarina cultivar (subgroup Prata), harvested the control at maturation stage 2 and at $10 \mathrm{DAH}$ was at stage 7 (very mature).

The bananas Prata-anã and Nanica stored at room temperature resulted in loss of fresh mass higher than the bananas refrigerated stored (Figure 3A). With this behavior, it is possible to verify the cooling efficiency in reducing the fresh mass loss of the Prata-anã and Nanica fruits, as we verified a reduction of $61.50 \%$ and $19.26 \%$ of fresh mass respectively, when compared to room temperature. It is also detected that the banana Prata-anã has higher fresh weight loss $(11.17 \%)$ than the Nanica (7.84\%) at room temperature, while for the refrigerated the loss was higher for Nanica $(6.33 \%)$ and lower for Prata-anã $(4.3 \%)$. In this sense, lower values were obtained by Castricini et al. (2015) when investigating the post-harvest and sensorial characterization of Pratatype banana genotypes found a reduction of fresh mass in mature fruits of Prata-anã bananas when compared to green fruits (6.69\%). Already Hattenhauer and Carvalho (2016) characterizing the physical and chemical aspects of the banana 'Nanica' harvested with different sizes (30 to $38 \mathrm{~mm}$ ) in two different seasons (February and November) in the municipality of Corupá, found that the loss of the fresh fruit mass of the mature fruits compared to the greens was $7.6 \%$ independent of the harvest season and ranged from 6.2 to $8.4 \%$ as a function of fruit diameter.

With the ethylene applications $-\mathrm{C}_{2} \mathrm{H}_{4}$ (Figure $3 \mathrm{~B})$, the Prata-anã cultivar showed a reduction of fresh mass loss until the second application (5.34\%) and then increased to the fifth application $(14.72 \%)$. The Nanica cultivar behaved in the opposite way, because the loss of fresh mass increased until the second application $(11.07 \%)$ and then the trend curve was decreasing until the fifth application (5.5\%). The fresh mass loss was higher for Nanica only during the second, third and fourth applications. This behavior can be explained by Sarmento et al. (2015), when they affirm that the loss of fresh mass is common during the storage of fruits and vegetables, which occurs by the consumption of nutrients in the own metabolism of the product and mainly by the loss of water caused by the transpiration processes and due to the difference of pressure between the product and the environment.

The loss of fresh mass increased with storage time (Figure 3C) for the Prata-anã (5 to 16.24\%) and Nanica (4.25 to $14.20 \%$ ) cultivars, although it was higher in all times for Prata-anã. The results presented in this research are superior to those reported by Falcão et al. (2017) studying the storage of banana Prata-anã and Grande Naine cultivars (Cavendish subgroup) under conditions of modified atmosphere with potassium permanganate, which verified that during the storage the largest mass loss for Prata-anã was $2.5 \%$ at 25 days of storage at room temperature $\left(27^{\circ} \mathrm{C}\right)$ under modified atmosphere conditions; however, for Grande Naine the greatest mass loss was $2.1 \%$ also at 25 days of storage, although under refrigeration temperature $\left(13^{\circ} \mathrm{C}\right)$ and absence of modified atmosphere. The values of mass loss by Falcão et al. (2017) are lower because in addition to their lower temperatures, modified atmosphere was used.

The highest reduction in fruit firmness was recorded for the Prata-anã banana (Figure 4A) in both storages (room temperature $26.74 \mathrm{~N}$ and refrigerated $26.84 \mathrm{~N}$ ). For Nanica the greatest reduction in firmness occurred at room temperature $(30.43 \mathrm{~N})$, while for Prata-anã there was no difference between the storage at room temperature and refrigerated. According to Chen et al. (2015), the firmness is a component of the texture that tends to reduce during the maturation, due mainly to the degradation of the cellular wall, occurring especially by the action of enzymes.

Figure $4 \mathrm{~B}$ shows a reduction in firmness as the number of ethylene $\left(\mathrm{C}_{2} \mathrm{H}_{4}\right)$ applications for both cultivars has increased, except between the control treatment and the first application in the Nanica cultivar and between the fourth and fifth applications in the Prata-anã cultivar, which did not differ among themselves, therefore, it is suggested to use only four applications for Prata-anã, thus reducing the cost of production, as well as more than one application for Nanica, since only one was not efficient in inducing maturation, since it matched the treatment without applying exogenous ethylene $\left(\mathrm{C}_{2} \mathrm{H}_{4}\right)$. Comparing the two cultivars, Prata-anã presented a greater reduction 
in firmness for all applications. These results are similar to those of Saraiva et al. (2018) by defining the harvest point and the concentration of exogenous ethylene $\left(\mathrm{C}_{2} \mathrm{H}_{4}\right)$ in bananas of cultivar Thap Maeo (genotype group AAB, subgroup Mysore), in which fruits firmness declined rapidly in the fruits treated with ethylene $-\mathrm{C}_{2} \mathrm{H}_{4}(0.01$, $0.1,0.5$ and $1.0 \mathrm{mg} / \mathrm{g}$ ), because in only two days the fruit pulp was three times softer, although the behavior of the ethylene $\left(\mathrm{C}_{2} \mathrm{H}_{4}\right)$ treated fruits did not differentiate between them.

The firmness was decreasing during the storage time for the Prata-anã and Nanica cultivars (Figure 4C), and the Prata-anã cultivar showed the greatest reduction at all times, except at the time of the $0 \mathrm{DAH}$, since there was no difference between the cultivars studied. The fruits of the Prata-anã cultivar showed a reduction of $41.24 \%$ in the firmness at time $0(49.32 \mathrm{~N})$ at time $3 \mathrm{DAH}(28.98 \mathrm{~N})$ and $71.28 \%$ at the end of the storage (10 DAH $14.16 \mathrm{~N})$; while the fruits of the Nanica cultivar showed a reduction of $28.02 \%$ in the firmness at time $0(49.32 \mathrm{~N})$ at time 3 DAH $(35.50 \mathrm{~N})$ and $62.73 \%$ at the end of the storage (10 DAH $18.38 \mathrm{~N})$. A similar result was found by Aquino et al. (2017) characterizing 15 cultivars of banana in two stages of maturation (immature and mature) in function of the morphological, physical and chemical aspects, which also detected a reduction in the firmness values of the pulp throughout the storage. The Prata-anã reduced from 44.41 to $6.73 \mathrm{~N}(84.84 \%)$ and the Nanica from 39.42 to $4.28 \mathrm{~N}$ (89.14\%). Already, Sarmento et al. (2015) studying the storage of Prata-catarina (Prata subgroup) under ambient conditions, observed that the firmness values of the fruits reduced as the maturation progressed (from 46.45 to $5.69 \mathrm{~N}$ at $10 \mathrm{DAH}$, that is, reduction of $87.58 \%$ ). These reductions in the firmness in the present study and in the aforementioned studies indicate the softening of the fruit as a function of the action of the pectinases and consequently the ripening of the fruit.

The total soluble solids of the Prata-anã banana (Figure 5A) when stored at ambient conditions $\left(12.59^{\circ}\right.$ Brix) was higher than that stored under refrigeration (11.96 ${ }^{\circ}$ Brix), whereas for Nanica there was no difference between storage conditions studied ( 7.62 and $7.72^{\circ}$ Brix, respectively). The total soluble solids of Prata-anã was superior to the Nanica, regardless of the storage condition. These results for Prata-anã were lower than those found by Sarmento et al. (2015) when they worked with Pratacatarina banana (Prata subgroup) stored at ambient conditions $\left(27.5^{\circ} \mathrm{C}\right)$, obtaining a maximum value of $24.1^{\circ}$ Brix at $8 \mathrm{DAH}$, indicating that the Prata-catarina bananas are in stadium of maturation more advanced than the Prata-anã. Therefore, the post-harvest shelf life of Prata-anã (10 DAH) will be higher than that of Pratacatarina (8 DAH).

Figure 5B shows increases in total soluble solids as the number of ethylene $\left(\mathrm{C}_{2} \mathrm{H}_{4}\right)$ applications for both cultivars has increased (from 4.99 to $15.21^{\circ}$ Brix for Prataanã and from 2.23 to $13.9^{\circ}$ Brix for Nanica), except for the fourth and fifth applications for the Nanica cultivar, which did not differ among them, therefore, it is suggested to use only four applications, so this reduces the cost of production. Comparing the two cultivars, Prata-anã presented total soluble solids higher in all applications. This behavior ratifies the study of Aquino et al. (2017) in 15 banana cultivars, which showed values of total soluble solids, respectively in immature and mature fruits, from 4.88 to $27.54^{\circ}$ Brix in Prata-anã and from 3.95 to $24.37^{\circ}$ Brix in Nanica. The increase in the total soluble solids contents during maturation is attributed mainly to the hydrolysis of the reserve carbohydrates accumulated during the growth of the fruit in the plant.

The total soluble solids (Figure 5C) were increasing over the storage time for the Prata-anã (from 1.23 to $18.94^{\circ}$ Brix) and Nanica (from 1.16 to $12.18^{\circ}$ Brix) cultivars, and that the Prata-anã cultivar was superior in all the times, except at time $0 \mathrm{DAH}$, because there was no difference between the cultivars studied. Similar behavior was observed by Siqueira et al. (2017) in Pacovan Ken bananas (from 2.0 to $18.5^{\circ} \mathrm{Brix}$ ) and Caipira (from 2.0 to $13.7^{\circ} \mathrm{Brix}$ ) stored at $25^{\circ} \mathrm{C}$ for 8 days. Therefore, the behavior of Pacovan Ken is to Prata-anã, just as the Caipira is to Nanica, because they belong to the same genomic groups, that is, AAB and AAA, respectively.

The bananas Prata-anã and Nanica stored at room temperature obtained a reduction in the total chlorophyll content of the upper peel in the refrigerated stored bananas (Figure 6A). With this behavior, it is possible to verify the efficiency of the refrigeration in reducing the degradation of the chlorophyll and consequently to delay the ripening. It is also detected that the Banana Prata-anã has a reduction in total chlorophyll content higher than the Nanica for both storage conditions (room temperature and refrigerated). These results are consistent with those of Siqueira et al. (2017), when they studied a modified atmosphere associated with refrigeration in the conservation of the Pacovan Ken and Caipira banana fruits, since they found that the Pacovan Ken fruits stored at $25^{\circ} \mathrm{C}$ and wrapped in 10 and $16 \mu \mathrm{m}$ films presented the coloring of the peel superior to the Caipira bananas under the same conditions, indicating a faster degradation of chlorophyll for Pacovan Ken, as well as for Prata-anã in this research.

Figure 6B shows a decrease in the total chlorophyll content of the peel as the number of ethylene $\left(\mathrm{C}_{2} \mathrm{H}_{4}\right)$ applications for both cultivars has increased. Prataanã presented lower total chlorophyll content for all applications. This behavior may be related to the degradation of chlorophyll by the enzyme chlorophyllase in the pericarp and the synthesis of carotenoids induced by the increase of ethylene $\left(\mathrm{C}_{2} \mathrm{H}_{4}\right)$, thus increasing the speed of metabolism and maturation (YANG et al., 2009).

The total chlorophyll content decreased during the 
storage time for the Prata-anã and Nanica cultivars (Figure 6C), however, at the time of $0 \mathrm{DAH}$ the total chlorophyll content of Prata-anã was higher than the Nanica, while Nanica was still superior to Prata-anã. These results are consistent with those of Siqueira et al. (2017) when they studied the refrigerated storage $\left(12.15\right.$ and $\left.25^{\circ} \mathrm{C}\right)$ of Pacovan Ken and Caipira bananas and found that with the advancement of maturation there was an increase in the yellow color of the peel regardless of the cultivar or the temperature of the unpackaged bananas. Since the changes in this characteristic are very evident for both genomic groups (AAB and $\mathrm{AAA}$ ), it is verified that the total chlorophyll analysis is adequate for the evaluation of the degree of the banana maturity and while the chlorophyll has decreased the peel color scale increased.

The total carotenoid contents of the peel and pulp of the Prata-anã and Nanica bananas when stored under ambient conditions were higher than those stored under refrigeration, and the carotenoids of the Prata-anã cultivar were superior to those of the Nanica cultivar, regardless of the storage condition (Figures 7A and 8A).

In Figures $7 \mathrm{~B}$ and $8 \mathrm{~B}$, significant increases were observed in the total carotenoids of the peel and pulp as the number of ethylene $\left(\mathrm{C}_{2} \mathrm{H}_{4}\right)$ applications for both cultivars has increased, except for Prata-anã pulp, which reached the maximum in the fourth application, therefore, it is suggested to use only four applications, as this reduces the cost of production. Comparing the two cultivars, Prata-anã showed the highest carotenoid content in all applications, indicating a faster degradation of chlorophyll and a greater synthesis of carotenoids. Therefore, Nanica's post-harvest shelf life will be higher than the Prata-anã.

The total carotenoid contents of the peel and the pulp were increasing during the storage time for the Prataanã and Nanica cultivars (Figures $7 \mathrm{C}$ and $8 \mathrm{C}$ ), with the Prata-anã cultivar superior at all times, except for the 4 DAH for the peel and 0 DAH for the pulp, in which the Nanica was superior.

The aforementioned results for the total carotenoid contents of the peel and pulp of the bananas studied corroborate with Castrini et al. (2006), when they state that both chlorophyll degradation and carotenoid synthesis are processes modulated by ethylene $\left(\mathrm{C}_{2} \mathrm{H}_{4}\right)$ during ripening, but color can also be a genetic characteristic, giving different nuances to the fruit peel, besides being an important indicator of the ideal harvesting point, as it was verified in this research that the total carotenoids of the peel and the pulp increased directly proportional to the color of the peel and inversely to the content of chlorophyll in the peel.

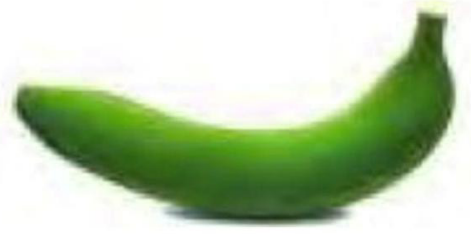

1. Totally green

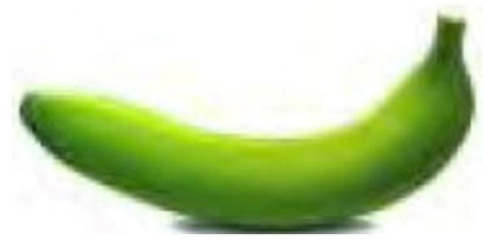

2. Green with yellow traits

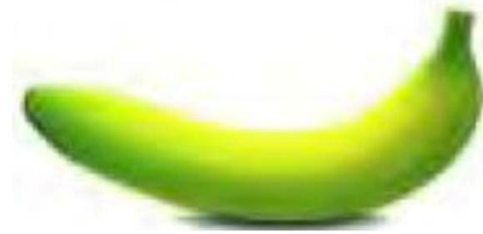

3. More green than yellow

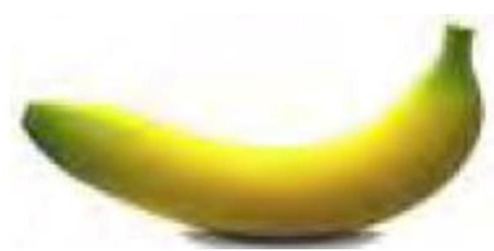

4. More yellow than green

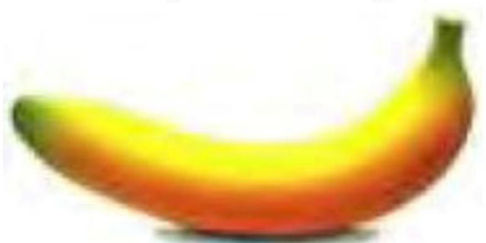

5. Yellow with green tip

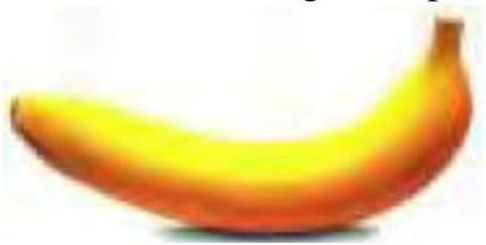

6. Yellow

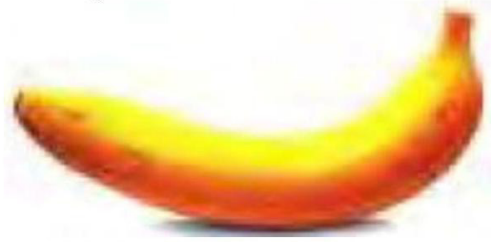

7. Yellow with brown spots

Figure 1- Von Loesecke maturation scale (PBMH \& PIF, 2006). 


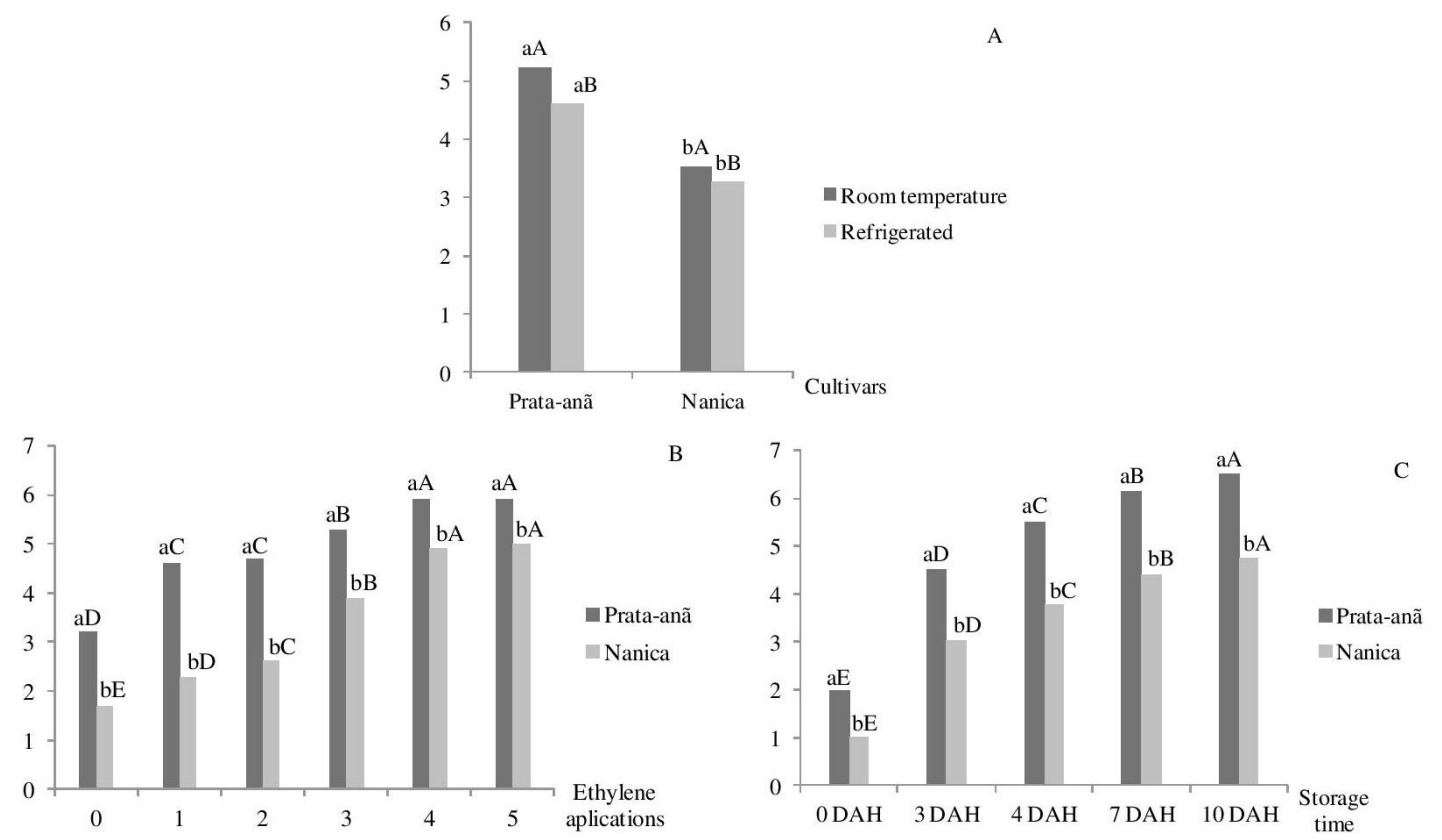

Figure 2. Von Loesecke scale for shell coloring; A - Banana cultivars at different storage temperatures; B - Cultivars of bananas in different ethylene applications $\left(\mathrm{C}_{2} \mathrm{H}_{4}\right) ; \mathrm{C}$ - Banana cultivars at different storage times (days after harvest - DAH).

* Means followed by the same lowercase letter at the same storage temperature or the same number of ethylene applications $\left(\mathrm{C}_{2} \mathrm{H}_{4}\right)$ or at the same time of storage and upper case in the same cultivar, do not differ among themselves by the test of Tukey, at the level of $5 \%$ of probability.
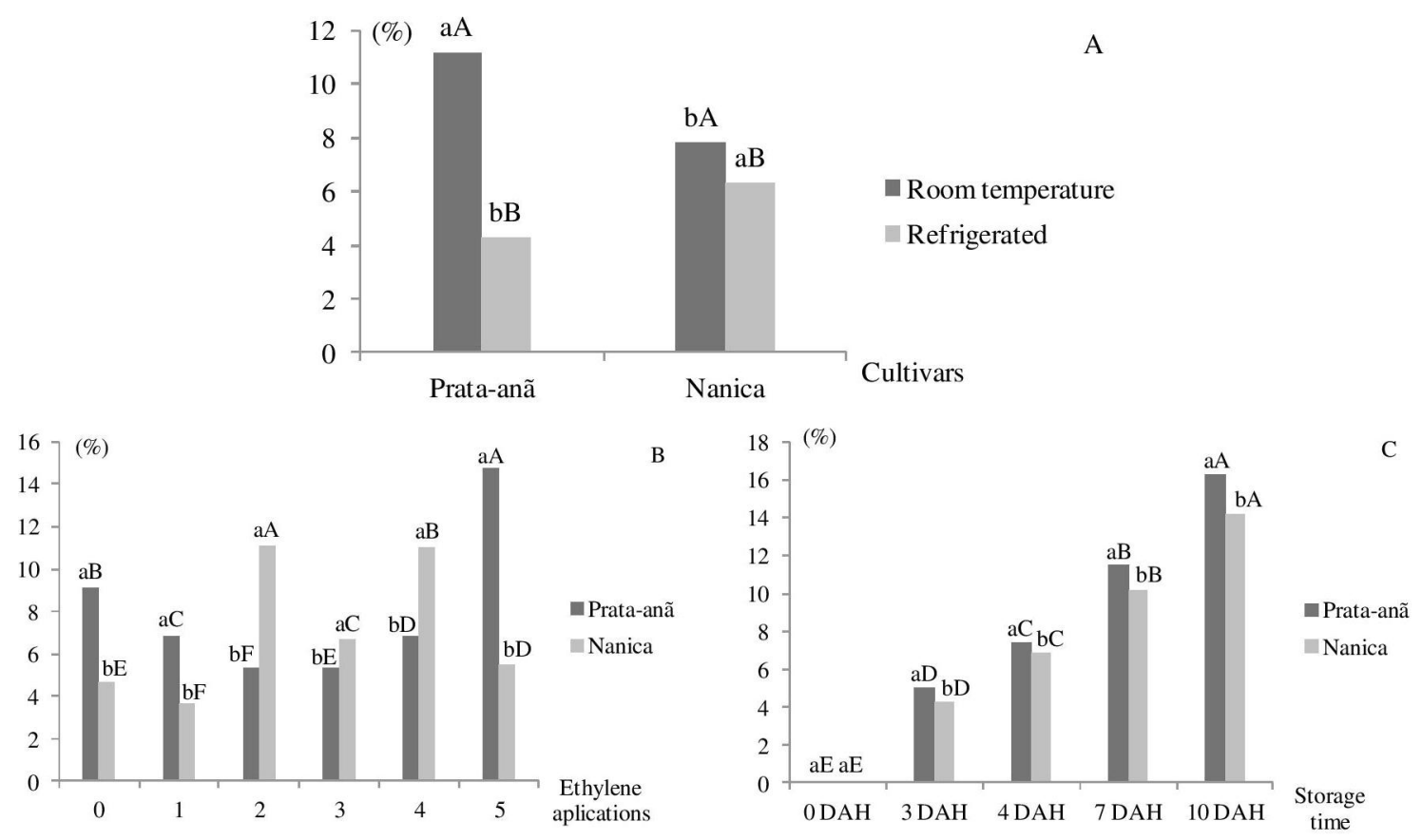

Figure 3. Loss of fresh mass (\%); A - Banana cultivars at different storage temperatures; B - Cultivars of bananas in different ethylene applications $\left(\mathrm{C}_{2} \mathrm{H}_{4}\right)$; C - Banana cultivars at different storage times (days after harvest - DAH).

* Means followed by the same lowercase letter at the same storage temperature or the same number of ethylene applications $\left(\mathrm{C}_{2} \mathrm{H}_{4}\right)$ or at the same time of storage and upper case in the same cultivar, do not differ among themselves by the Tukey test, at the level of $5 \%$ probability. 

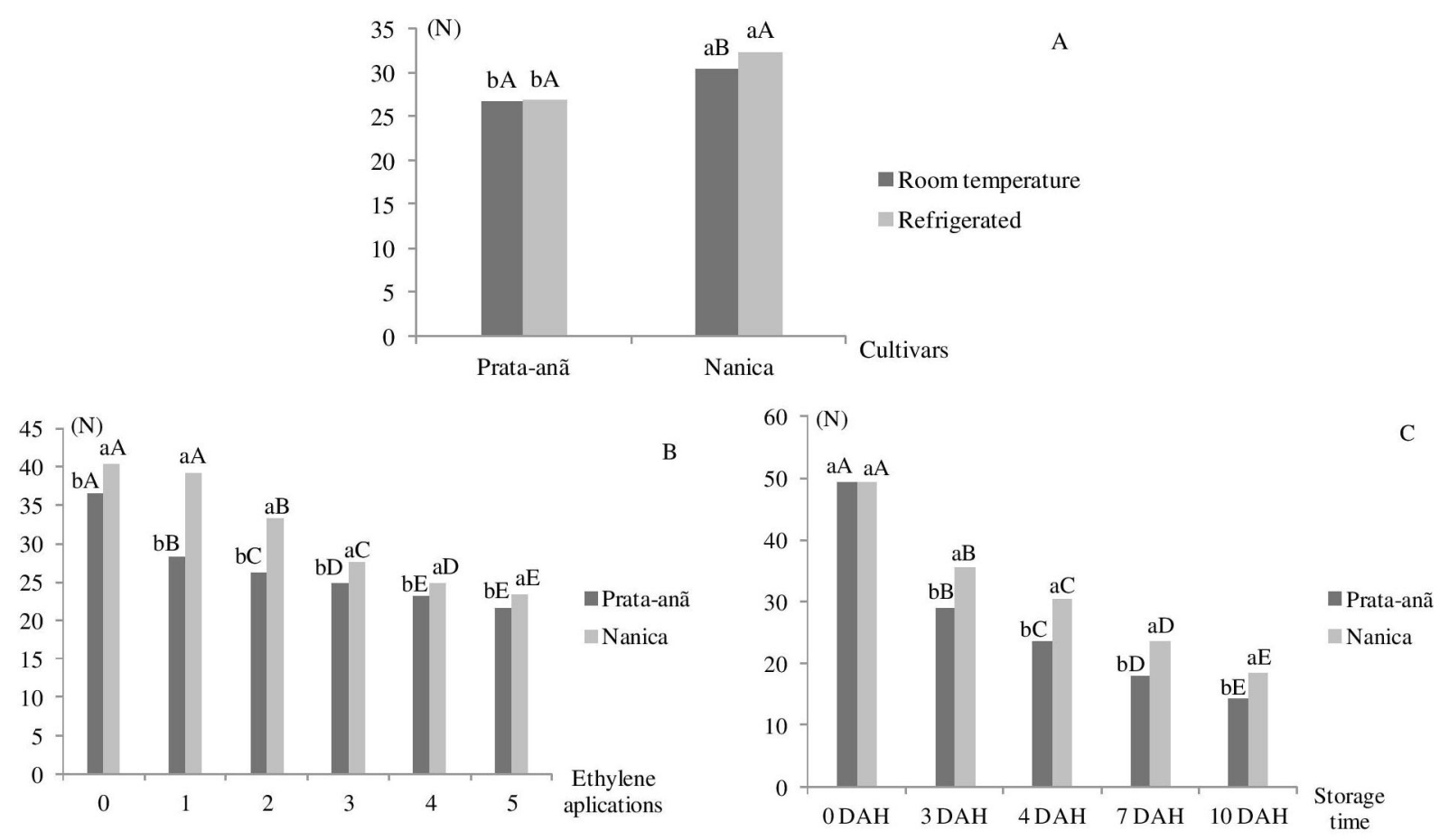

Figure 4. Firmness (N); A - Banana cultivars at different storage temperatures; B - Cultivars of bananas in different ethylene applications $\left(\mathrm{C}_{2} \mathrm{H}_{4}\right)$; C - Banana cultivars at different storage times (days after harvest - DAH).

*Means followed by the same lowercase letter at the same storage temperature or the same number of ethylene applications $\left(\mathrm{C}_{2} \mathrm{H}_{4}\right)$ or at the same time of storage and upper case in the same cultivar, do not differ among themselves by the test of Tukey, at the level of $5 \%$ of probability.
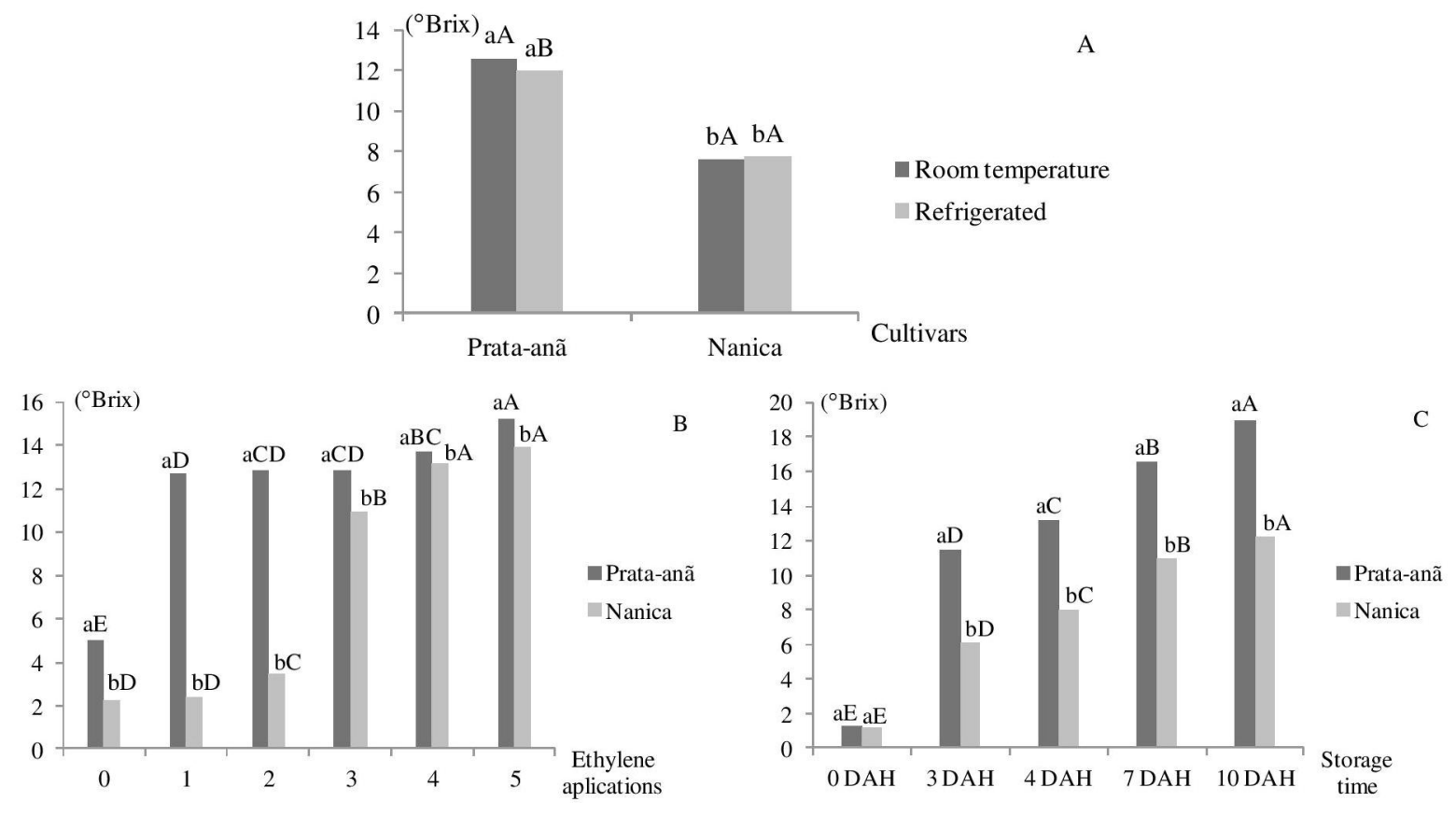

Figure 5. Total soluble solids ( $\left.{ }^{\circ} \mathrm{Brix}\right)$; A - Banana cultivars at different storage temperatures; B - Cultivars of bananas in different ethylene applications $\left(\mathrm{C}_{2} \mathrm{H}_{4}\right) ; \mathrm{C}$ - Banana cultivars at different storage times (days after harvest - DAH).

* Means followed by the same lowercase letter at the same storage temperature or the same number of ethylene applications $\left(\mathrm{C}_{2} \mathrm{H}_{4}\right)$ or at the same time of storage and upper case in the same cultivar, do not differ among themselves by the test of Tukey, at the level of $5 \%$ of probability. 

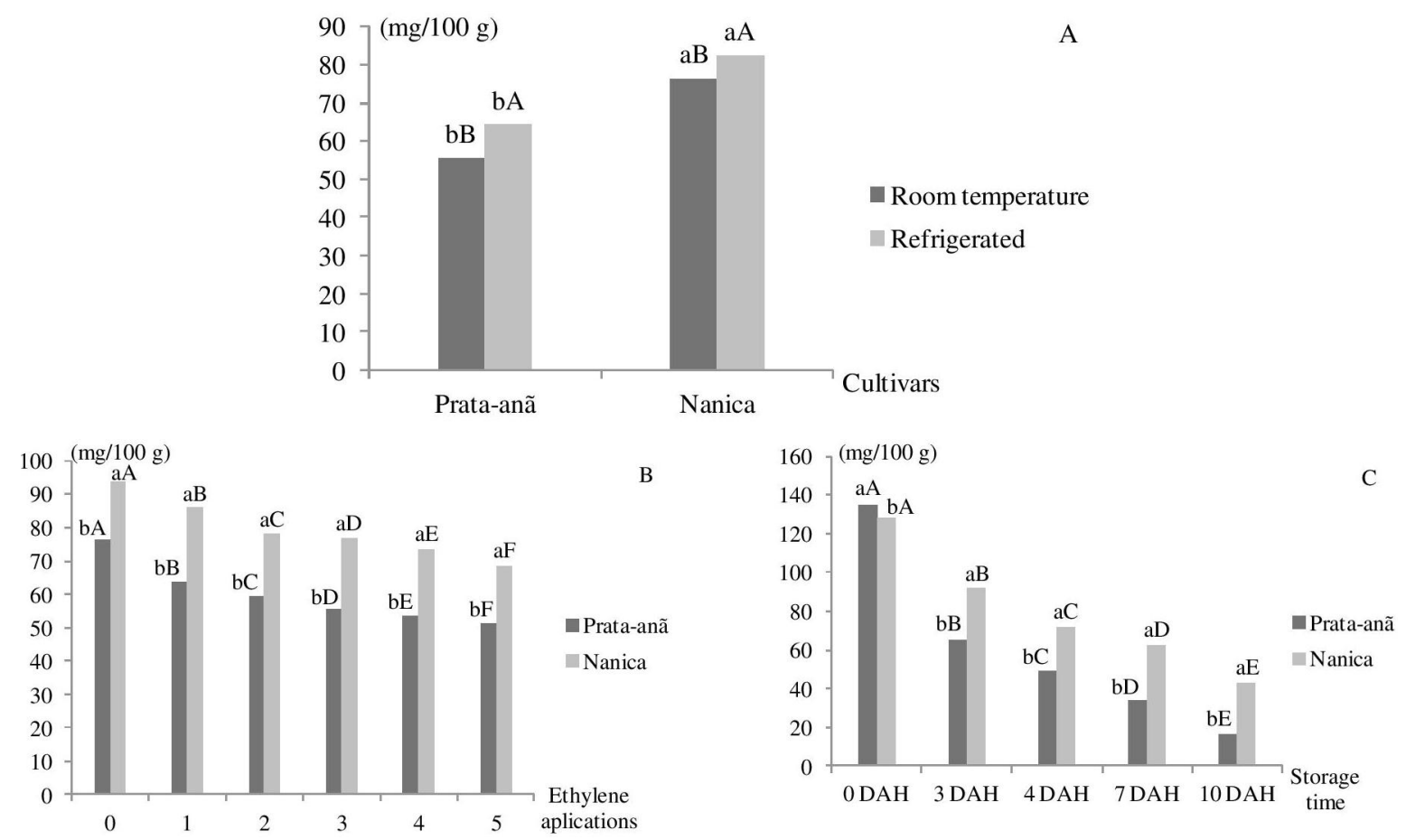

Figure 6. Total peel chlorophyll (mg / $100 \mathrm{~g}$ ); A - Banana cultivars at different storage temperatures; B - Cultivars of bananas in different ethylene applications $\left(\mathrm{C}_{2} \mathrm{H}_{4}\right) ; \mathrm{C}$ - Banana cultivars at different storage times (days after harvest - DAH).

*Means followed by the same lowercase letter at the same storage temperature or the same number of ethylene applications $\left(\mathrm{C}_{2} \mathrm{H}_{4}\right)$ or at the same time of storage and upper case in the same cultivar, do not differ among themselves by the Tukey test, at the level of 5\% probability.
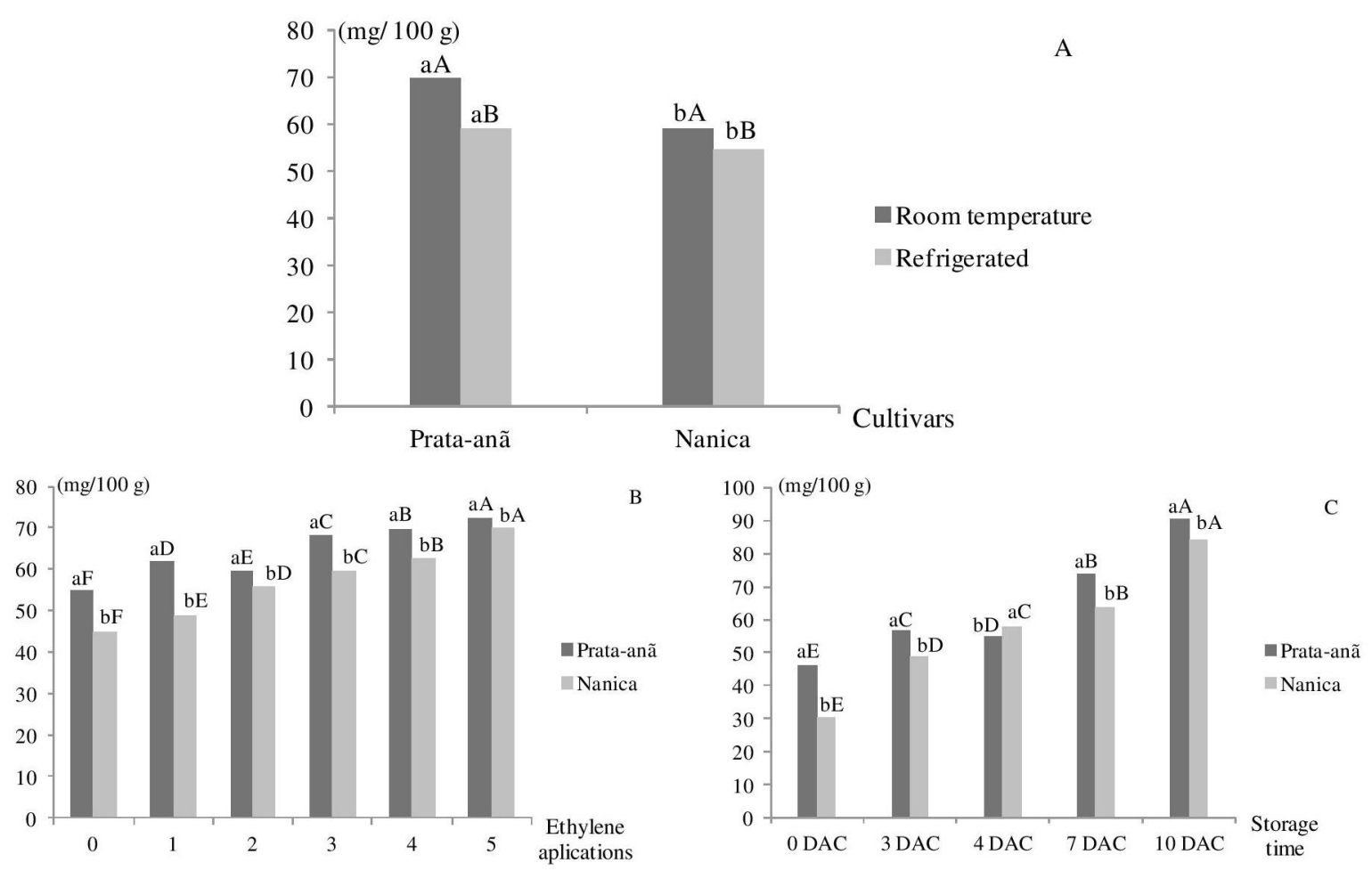

Figure 7. Total peel carotenoids (mg / $100 \mathrm{~g}$ ); A - Banana cultivars at different storage temperatures; B - Cultivars of bananas in different ethylene applications $\left(\mathrm{C}_{2} \mathrm{H}_{4}\right) ; \mathrm{C}$ - Banana cultivars at different storage times (days after harvest - DAH).

* Means followed by the same lowercase letter at the same storage temperature or the same number of ethylene applications $\left(\mathrm{C}_{2} \mathrm{H}_{4}\right)$ or at the same time of storage and upper case in the same cultivar, do not differ among themselves by the Tukey test, at the level of $5 \%$ probability. 

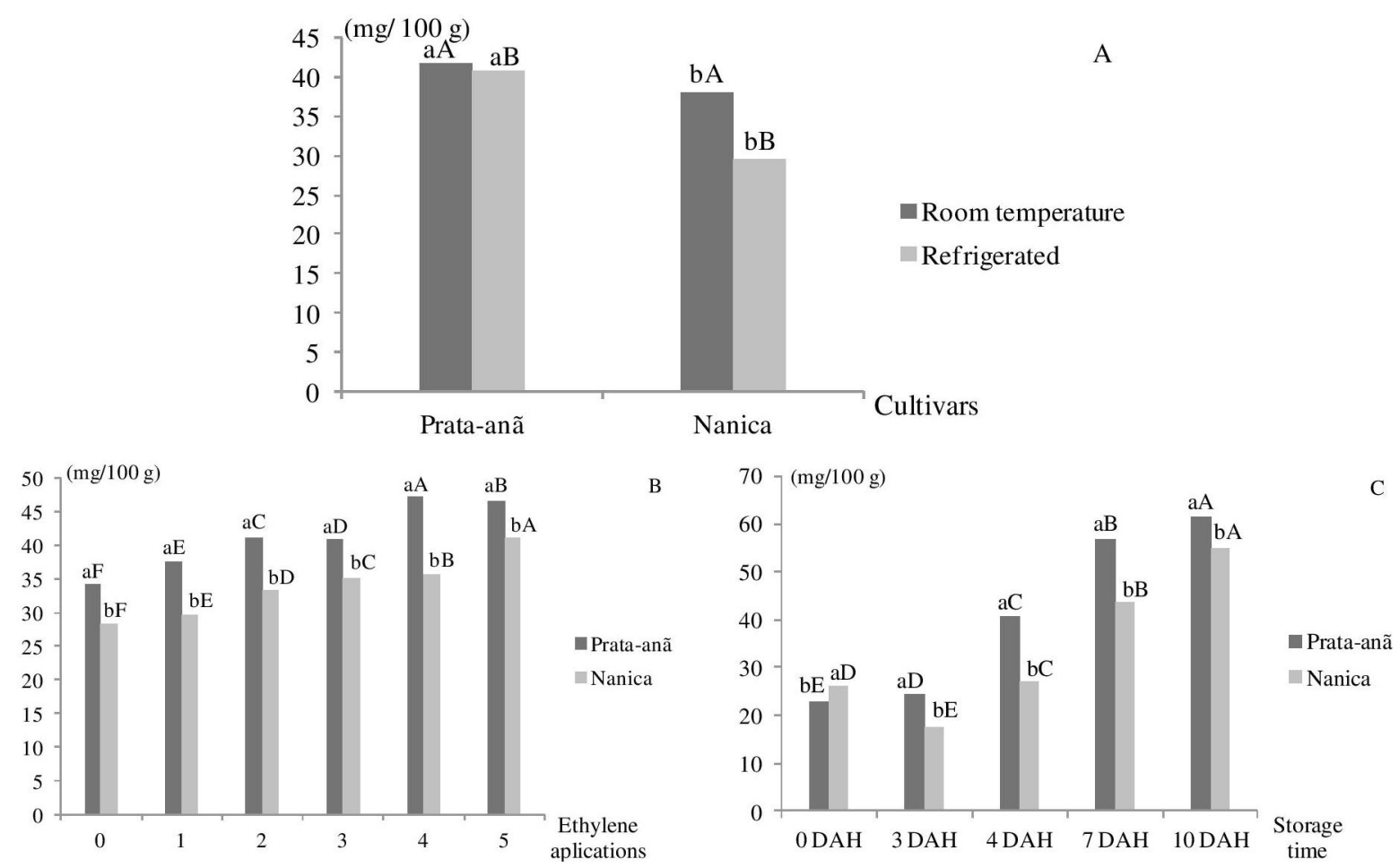

Figure 8. Total pulp carotenoids (mg / $100 \mathrm{~g}$ ); A - Banana cultivars at different storage temperatures; B - Cultivars of bananas in different ethylene applications $\left(\mathrm{C}_{2} \mathrm{H}_{4}\right) ; \mathrm{C}$ - Banana cultivars at different storage times (days after harvest - DAH).

* Means followed by the same lowercase letter at the same storage temperature or the same number of ethylene applications $\left(\mathrm{C}_{2} \mathrm{H}_{4}\right)$ or at the same time of storage and upper case in the same cultivar, do not differ among themselves by the Tukey test, at the level of 5\% probability.

\section{Conclusions}

- The temperature of $15^{\circ} \mathrm{C}$ decreases the maturation process of the bananas Prata-anã and Nanica, as well as, it provides maintenance of the physical-chemical characteristics of the same.

- The banana Prata-anã is more sensitive to the ethylene action $\left(\mathrm{C}_{2} \mathrm{H}_{4}\right)$ than the banana Nanica.

- The bananas Prata-anã and Nanica harvested respectively, with 18 and 13 weeks support $10 \mathrm{DAH}$ with good maintenance of the physical-chemical characteristics.

\section{Acknowledgements}

The authors would like to thank the Coordination of Improvement of Higher Education Personnel (CAPES) for granting the Doctorate Grant to the first author; to the Sitio Barreiras for logistical support.

\section{References}

AQUINO, C.F; SALOMÃO, L.C.C; CECON, P.R; SIQUEIRA, D.L; RIBEIRO, S.M.R. Physical, chemical and morphological characteristics of banana cultivars depending on maturation stages. Revista Caatinga, Mossoró, v.30, n.1, p.87-96, 2017.
CASTRICINI, A.; SANTOS, L.O.; DELIZA, R.; COELHO, E.F.; RODRIGUES, M.G.V.; Caracterização pós-colheita e sensorial de genótipos de bananeiras tipo Prata. Revista Brasileira de Fruticultura, Jaboticabal, v.37, n.1, p.27-37, 2015.

CHEN, H.; CAO, S.; FANG, X.; MU, H.; YANG, H.; WANG, X.; XU, Q.; GAO, H. Changes in fruit firmness, cell wall composition and cell wall degrading enzymes in postharvest blueberries during storage. Scientia Horticulturae, Amsterdam, v.188, p.44-48, 2015.

CHITARra, M. I. F.; CHITARRA, A. B. Pós-colheita de frutas e hortaliças: fisiologia e manuseio. 2. ed. rev. e ampl. Lavras: UFLA, 2005. 785 p.

DALE, J.; PAUL, J-Y.; DUGDALE, B.; HARDING, R. Modifying bananas: from transgenics to organics? Sustainability, Basel, v.9, n.333, p.1-13, 2017.

FALCÃO, H.A.S.; FONSECA, A.O.; OLIVEIRA FILHO, J.G.; PIRES, M.C.; PEIXOTO, J.R. Armazenamento de variedades de bananas em condições de atmosfera modificada com permanganato de potássio. Revista de Agricultura Neotropical, Cassilândia, v.4, n.4, p.1-7, 2017. 
FAO - Food and Agriculture Organization of the United Nations. FAOSTAT data. Rome: FAO, 2014. Disponível em: $<$ http://www.fao.org/faostat/en/\#data $>$. Acesso em: 02 jul. 2017.

HATTENHAUER, S.K.; CARVALHO, R.I.N. Caracterização física e química da banana 'Nanica' em função da época de colheita e do diâmetro do fruto em Corupá, SC. Agropecuária Catarinense, Florianópolis, v.29, n.2, p.80-83, 2016.

IAL - Instituto Adolfo Lutz. Métodos físico-químicos para análise de alimentos. 4.ed. São Paulo: IAL, 2008. 1020p.

IBGE - Instituto Brasileiro de Geografia e Estatística. Levantamento sistemático da produção agrícola: pesquisa mensal de previsão e acompanhamento das safras agrícolas no ano civil janeiro 2015. Rio de Janeiro: IBGE, 2015. 83p. Disponível em:<ftp://ftp.ibge.gov. br/Producao Agricola/Levantamento Sistematico da Producao_Agricola_\%5Bmensal\%5D/Fasciculo/2015/ 1spa 201501.pdf>. Acesso em: 02 jul. 2017.

IBGE - Instituto Brasileiro de Geografia e Estatística. Produção agrícola municipal - lavoura permanente 2015: Ceará - Missão Velha. Rio de Janeiro: IBGE, 2016. Disponível em: $<\mathrm{http}: / /$ cidades.ibge.gov.br/xtras/temas. php?lang $=$ \& codmun $=230840 \&$ idtema $=157 \&$ search $=$ ce ara|missao-velha|producao-agricola-municipal-lavourapermanente-2015>. Acesso em: 02 jun. 2017.

LICHTENTHALER, H.K. Chlorophylls and carotenoids: pigments of photosynthetic biomembranes. Methods in Enzymology, San Diego, v.148, n.22, p.350-382, 1987.

MAIA, L.C.B.; MAIA, V.M.; SALOMÃO, L.C.C.; SALLES, B.P.A.; PEGORARO, R.F. Alterações metabólicas em bananas induzidas por dano mecânico. Revista Unimontes Científica, Montes Claros, v.17, n.2, p.27-34, 2015.

MORENO, N.B.C.; SILVA, A.A.; SILVA, D.F. Análise de variáveis meteorológicas para indicação de áreas agrícolas aptas para banana e caju no Estado do Ceará. Revista Brasileira de Geografia Física, Recife, v.9, n.1, p.1-15, 2016.

PAULO, B.K.; Efeitos de concentrações de etileno e temperaturas na climatização de bananas de regiões subtropicais. 2010. 95f. Dissertação (Mestrado em Fitotecnia) - Faculdade de Agronomia, Universidade Federal do Rio Grande do Sul, Porto Alegre, 2010.
PBMH \& PIF - Programa Brasileiro para a Modernização da Horticultura \& Produção Integrada de Frutas. Normas de classificação de banana. São Paulo: CEAGESP, 2006. (Documentos, 29).

PEREIRA, M.C.T; SALOMÃO, L.C.C.; SANTOS, R.C.; SILVA, S.O.; CECON, P.R.; NIETSCHE, S. Aplicação em pré-colheita de cloreto de cálcio no controle do despencamento natural dos frutos de bananeira 'FHIA18'. Ciência Rural, Santa Maria, v.45, n.11, p.1925-1931, 2015.

SANTOS, L.O.; MARTINS, R.N.; CASTRICINI, A.; RODRIGUES, M.G.V.; DIAS, M.S.C. 'Prata-anã' banana conservation at $12^{\circ} \mathrm{C}$ and $14^{\circ} \mathrm{C}$ under controlled atmosphere. Científica, Jaboticabal, v.45, n.1, p.57-63, 2017.

SARAIVA, L.A.; CASTELAN, F.P.; GOMES B.L.; PURGATTO, E.; CORDENUNSI-LYSENKO, B.R. Thap Maeo bananas: fast ripening and full ethylene perception at low doses. Food Research International, Burlington, v.105, p.384-392, 2018.

SARMENTO, D.H.A.; SOUZA, P.A.; SARMENTO, J.D.A.; FREITAS, R.V.S.; SALGADO FILHO, M. Armazenamento de banana 'Prata catarina' sob temperatura ambiente recobertas com fécula de mandioca e PVC. Revista Caatinga, Mossoró, v.28, n.2, p.235-241, 2015.

SILVA, F.A.S.; AZEVEDO, C.A.V. The Assistat Software Version 7.7 and its use in the analysis of experimental data. African Journal of Agricultural Research, Ebène, v.11, n.39, p.3733-3740, 2016.

SIQUEIRA, C.L.; ALMEIDA, H.J.; SERPA, M.F.P.; BATISTA, P.S.C.; MIZOBUTSI, G.P. Modified atmosphere together with refrigeration in the conservation of bananas resistant to black Sigatoka. Revista Ciência Agronômica, Fortaleza, v.48, n.4, p.614-624, 2017.

YANG, X.; ZHANG, Z.; JOYCE, D.; HUANG, X.; XU, L.; PANG, X. Characterization of chlorophyll degradation in banana and plantain during ripening at high temperature. Food Chemistry, Reading, v.114, n.2, p.383-390, 2009. 